\title{
Front Matter: Volume 11701
}

, "Front Matter: Volume 11701," Proc. SPIE 11701, Complex Light and Optical Forces XV, 1170101 (12 April 2021); doi: 10.1117/12.2596549

SPIE. Event: SPIE OPTO, 2021, Online Only 


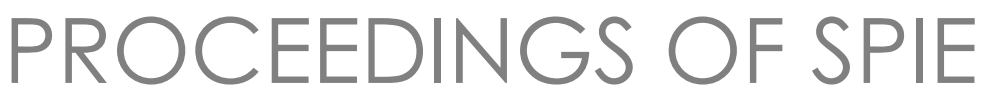

\title{
Complex Light and Optical Forces XV
}

\author{
Enrique J. Galvez \\ Halina Rubinsztein-Dunlop \\ David L. Andrews \\ Editors
}

6-11 March 2021

Online Only, United States

Sponsored and Published by

SPIE 
The papers in this volume were part of the technical conference cited on the cover and title page. Papers were selected and subject to review by the editors and conference program committee. Some conference presentations may not be available for publication. Additional papers and presentation recordings may be available online in the SPIE Digital Library at SPIEDigitalLibrary.org.

The papers reflect the work and thoughts of the authors and are published herein as submitted. The publisher is not responsible for the validity of the information or for any outcomes resulting from reliance thereon.

Please use the following format to cite material from these proceedings:

Author(s), "Title of Paper," in Complex Light and Optical Forces XV, edited by Enrique J. Galvez, Halina Rubinsztein-Dunlop, David L. Andrews, Proceedings of SPIE Vol. 11701 (SPIE, Bellingham, WA, 2021) Seven-digit Article CID Number.

ISSN: 0277-786X

ISSN: 1996-756X (electronic)

ISBN: 9781510642379

ISBN: 9781510642386 (electronic)

Published by

SPIE

P.O. Box 10, Bellingham, Washington 98227-0010 USA

Telephone +1 3606763290 (Pacific Time) · Fax +1 3606471445

SPIE.org

Copyright (c) 2021, Society of Photo-Optical Instrumentation Engineers.

Copying of material in this book for internal or personal use, or for the internal or personal use of specific clients, beyond the fair use provisions granted by the U.S. Copyright Law is authorized by SPIE subject to payment of copying fees. The Transactional Reporting Service base fee for this volume is $\$ 21.00$ per article (or portion thereof), which should be paid directly to the Copyright Clearance Center (CCC), 222 Rosewood Drive, Danvers, MA 01923. Payment may also be made electronically through CCC Online at copyright.com. Other copying for republication, resale, advertising or promotion, or any form of systematic or multiple reproduction of any material in this book is prohibited except with permission in writing from the publisher. The CCC fee code is $0277-$ $786 \mathrm{X} / 21 / \$ 21.00$.

Printed in the United States of America by Curran Associates, Inc., under license from SPIE.

Publication of record for individual papers is online in the SPIE Digital Library.

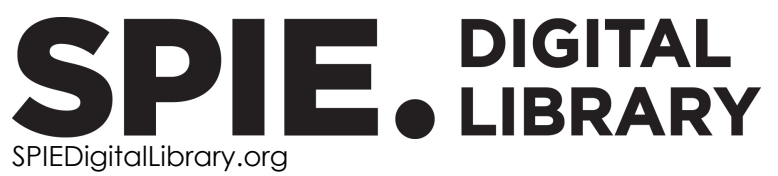

Paper Numbering: Proceedings of SPIE follow an e-First publication model. A unique citation identifier (CID) number is assigned to each article at the time of publication. Utilization of CIDs allows articles to be fully citable as soon as they are published online, and connects the same identifier to all online and print versions of the publication. SPIE uses a seven-digit CID article numbering system structured as follows:

- The first five digits correspond to the SPIE volume number.

- The last two digits indicate publication order within the volume using a Base 36 numbering system employing both numerals and letters. These two-number sets start with $00,01,02,03,04$, 05, 06, 07, 08, 09, OA, OB ... 0Z, followed by 10-1Z, 20-2Z, etc. The CID Number appears on each page of the manuscript. 


\section{Contents}

WORKSHOP ON METHODS OF COMPLEX LIGHT

1170105 Structuring light with digital micro-mirror devices [1 1701-44]

1170106 Remote quantum optics labs [11701-43]

FUNDAMENTAL OAM

11701 OD Longitudinal fields of quantized Laguerre-Gaussian modes [1 1701-7]

SPATIAL POLARIZATION

$117010 N \quad$ Interferometric polarimetry using full-Poincaré beams [11701-17]

3D MODE EFFECTS

$117010 \mathrm{U}$ Einstein beams: optical beams following gravitationally lensed trajectories [11701-24]

$117010 \mathrm{~V}$ Tailored spectral rotation of vortex pulses by non-uniform spiral phase gratings [11701-25]

LIGHT AND NANOSTRUCTURES

11701 OY Discrete dipole approximation simulation of optical vortex excited plasmonic properties of a partially capped core-shell nanostructure [11701-27]

1170110 Extending range through structured back focal plane interferometry [11701-29]

TRAPPING FIELDS

1170113 Giant optical forces using an array of asymmetric split-ring plasmonic nanostructures [11701-32]

$1170116 \quad$ Algorithmic considerations for complex light [11701-35] 
NOVEL TRAPPING

11701 1A High-resolution and massive trapping and separation of dielectric nanoparticles in an optical potential well array [11701-39]

OPTICAL TWEEZERS

11701 1D GPC-modalities for neurophotonics and optogenetics [11701-42]

POSTER SESSION

11701 1F Generation of polarization singularities using propagating cylindrical vector beams [11701-47] 